\title{
Semantic Content of Turkish Children's Private Speech
}

\author{
Emel Uçar ${ }^{1}$, Hatice Sofu ${ }^{2}$ \\ ORCID: ${ }^{1} 0000-0002-0436-5360,{ }^{2} 0000-0002-5859-1718$ \\ ${ }^{1}$ Çukurova University, School of Foreign Languages, Adana \\ ${ }^{2}$ Çukurova University, Department of English Language Teaching, Adana \\ ${ }^{1}$ ucaremel@hotmail.com, ${ }^{2}$ hasofu@cu.edu.tr
}

(Received 28 June 2020; Accepted 30 December 2021)

\begin{abstract}
In the present study, the content of private speech that Turkish monolingual children produced was investigated. Data were obtained from 28 children between the ages of 3;1 and 5;7 in three age groups while they were playing with a wooden toy house and its figures. The content categories of Winsler et al. (2003) were used in this study with a slight alteration in one of the categories due to the nature of the data. The results obtained in this study presented both similarities and differences with the existing literature. Children in all age groups produced the highest amount of private speech in Description of the Environment and Task category. There were no private speech utterances in Motivational/Evaluative Statements in children's private speech. The results suggest that planning, problem solving and self-regulatory functions of private speech are represented in its content. In addition, linguistic and pragmatic features of social speech are observed in the content and language of private speech.
\end{abstract}

Keywords: Private speech, planning, self-regulation, functions of language

\section{Türkçe Edinen Çocukların Kendi Kendine Konuşmalarının Anlamsal İçeriği}

ÖZ: Bu çalışmada Türkçeyi anadil olarak edinen tek dilli çocukların kendi kendilerine konuşmalarındaki içerik özellikleri incelenmiştir. Çalışmanın verisi, yaşları 3;1 ile 5;7 arasında olan üç yaş grubundan 28 çocuğun oyuncak ahşap bir ev ve onun parçalarıyla kendi kendilerine oynarken ürettikleri konuşmalardan elde edilmiştir. Bu çalışmada Winsler ve ark. (2003) tarafından oluşturulan içerik kategorileri kullanılmış ancak bu çalışmada elde edilen veriye özgü olarak bir kategoride değişiklik yapılmıştır. Bu çalışmada elde edilen sonuçlar var olan alan yazınla hem benzerlikler hem de farklılıklar ortaya 
koymuştur. Tüm yaş gruplarındaki çocuklar en fazla Çevre ve Görevi Tanımlama kategorisinde kendi kendine konuşma üretmiştir. Çocukların kendi kendine konuşmalarında Motivasyon/Değerlendirme İçeren Cümlelere rastlanmamıştır. Sonuçlar gösteriyor ki kendi kendine konuşmanın planlama, problem çözme ve öz düzenleme işlevleri konuşmanın içeriğinde görülmektedir. Ayrıca kişiler arası konuşmanın dilsel ve edimsel özellikleri kendi kendine yapılan konuşmada kullanılan dilde ve içeriğinde gözlemlenmiştir.

Anahtar sözcükler: Kendi kendine konuşma, planlama, öz düzenleme, dilin işlevleri

\section{Introduction}

Private speech is the audible or visible speech that children use to communicate with themselves as they go on their daily activities (Berk, 1992; 1994). It starts at around age three and diminishes through age seven and transforms into inner speech which is defined as verbalized thought emerging in people's minds when they are planning, organizing or solving a problem (Vygotsky, 1986).

Although there has always been private speech along with social speech, it did not get attention until the beginning of the last century. Starting with Piaget and Vygotsky in the early 1900s, its implications for cognitive and language development are realized. Having common points in explaining the developmental theory, they have different approaches as to the functions of private speech. Piaget (1962) had pointed out that egocentric speech, in his terms, did not have a positive effect on cognitive development. According to Piaget, for normally developing children, the term egocentric is identified with three types of utterances: echolalia which is defined as a repetitive process of sounds and syllables for playful purposes; monologs referring to speeches that a child gives apparently for his/her own personal benefit; and collective monologues in which two or more children simultaneously present monologs to one another without paying attention if the others comprehend or respond. In Piaget's terms, this egocentric speech comes from immature minds and exists because children have difficulty in imagining others' perspectives. Therefore, he claims much of their private speech serves little communication function. He also believed that this speech gradually disappears and children become capable of real social interaction.

On the other hand, Vygotsky views private speech differently. He thinks that the function of private speech is not only to accompany the child's activity but to "serve mental orientation, conscious understanding; it helps in overcoming difficulties; it is speech for oneself, intimately and usefully connected with the child's thinking." (1986, p. 228) 
According to Vygotsky, the features of reality a child is ready to master are within zone of proximal (or potential) development. The child's performance in doing activities and accomplishing tasks on his own and with the help of someone else is not the same. Vygotsky states that zone of proximal development includes the performances in which the child and the adult discuss the task and the child tries to accomplish the task with the guidance of the adult. In the same way, when he or she is alone the "child incorporates the language of those dialogues into his/her private speech and then uses it to guide independent efforts" (Berk, 1994, p. 79) Therefore, unlike Piaget's view claiming that the private speech had no implication for and leads to social communication eventually, Vygotsky proposed that early social communication between the adult and the child gives rise to private speech providing a stimulus for further development of psychological functions such as planning, executive functioning and self-regulation.

There has been numerous research on various aspects of private speech such as its content, function and the language used in private speech. Although content and function terms are sometimes used interchangeably, Diaz (1992) stated that the function of private speech means the possible consequences of the expression for the person's ongoing behaviour. He exemplified the functional categories as follows: If the child utters, "I am riding this" as s/he does the action, the category of this utterance is self-guiding. However, if it occurs before the action, the category could be planning.

In the private speech context, content means the "referential aspects of the utterance that is what the child is talking about" (Diaz, 1992). Scholars have created their own categories in terms of the content of private speech (Copeland, 1979; Rubin and Dyck, 1980; Diaz et al., 1992; Krafft \& Berk, 1998). In all of these categorizations, the common point is that they put the private speech into one of these subcategories with the same or similar names: description or comments about self (e.g., "I am riding this") and description or comments about the task (e.g. "The yellow chair"), planning, exclamations, word plays, questions, inaudible mutterings and uncategorized speech "other" categories.

In the present study, the analysis is based basically on the comprehensive semantic categories of Winsler et al. (2003) with a few alterations in the categories. There are a total of 11 content categories.

Studies on the private speech of Turkish children are quite limited. In addition to a literature review comparing the views of Vygotsky, Piaget and Watson in terms of private speech by Demir (2010), Bayhan and Saranli (2010) present the definition and categories of private speech among preschool children, areas, reasons, and examples why children need private speech as well as a comparison of Vygotsky's and Piaget's views on private speech. In their study, Keleş and Alisinanoğlu (2014) investigated the observations and ideas of 44 pre-school teachers on private speech patterns of children. The findings of the participants' 
observations were categorized into four regarding the context of private speech, content of private speech, the functions and developmental effects of private speech. For the first category, the most private speech was observed while playing with blocks while the least was in picture matching. For the second category, the highest frequency was in defining the activity they were involved in and the lowest was asking themselves questions and answering them. For the third category, they found out a mutual emphasis mostly on descriptive and motivational functions of private speech. For the last category, both the effects on individual development and on other children's development were examined separately, and in both cases positive effects were reported. A study by Öztemür (2018) investigated the relationship among executive functioning, private speech and emotion regulation. She suggested that private speech may have a supportive function for children who have disadvantage in inhibition control.

It is clear that studies on Turkish children's private speech needs to be expanded on every aspect of it. The present study aims to focus on the content of private speech produced by Turkish children and present its implications for cognitive development.

\section{Methodology}

This section introduces the participants, the framework of the analysis, the data collection procedure and the data analysis of this study.

\subsection{Participants}

In this stage, data were collected from a total of 56 children ranging in age $3 ; 1$ and 5;7. The participants were chosen with convenience sampling as they attended the kindergarten in Çukurova University campus except for four of the children in the three-year-olds' group. As there were not enough children available in the kindergarten in that age group, we included four children from her neighbourhood or among relatives of the children who also attended a different kindergarten. The mothers of these children shared the same characteristics as the mothers of children from the kindergarten in terms of educational background. The setting during the private speech and mother-child video recordings were also arranged in a way that would be closest to the recordings in the kindergarten. 
Table 1. Participants

\begin{tabular}{ccccc}
\hline Age & $\begin{array}{c}\text { Children Who } \\
\text { Produced } \\
\text { Private Speech }\end{array}$ & $\begin{array}{c}\text { Children Who } \\
\text { Whispered or } \\
\text { Produced } \\
\text { Inaudible } \\
\text { Mutterings }\end{array}$ & $\begin{array}{c}\text { Children Who } \\
\text { did not } \\
\text { Produce } \\
\text { Private Speech }\end{array}$ & Total \\
\hline Age 5 & 10 & 6 & 3 & 19 \\
Age 4 & 10 & 1 & 11 & 22 \\
Age 3 & 8 & 2 & 5 & 15 \\
\hline Total: & 28 & 9 & 19 & 56 \\
\hline
\end{tabular}

Among 56 participants, 19 of them did not produce any audible private speech, and nine of them produced private speech which was in the form of whisper and inaudible mutterings, therefore they were not included in the analysis. Hence, 28 of the participants who produced audible private speech were included in the lexical and content analysis.

Table 2. Profile of the participants

\begin{tabular}{llccc}
\hline Age Groups & & Age 3 & Age 4 & Age 5 \\
\hline $\begin{array}{l}\text { Number of } \\
\text { participants who } \\
\text { produced private }\end{array}$ & & & & \\
speech & 8 & 10 & 10 \\
Age & Mean age & $3 ; 3$ & $4 ; 3$ & $5 ; 1$ \\
& Age range & $3 ; 1-3 ; 11$ & $4 ; 0-4 ; 11$ & $5 ; 0-5 ; 7$ \\
Gender & $\begin{array}{l}\text { Female } \\
\text { Male }\end{array}$ & 6 & 6 & 3 \\
\hline
\end{tabular}

The profile of the participants is shown in Table 1 . In the first age group there are eight three-year-old children (mean age: 3;3, range: 3;1-3;11, two boys and six girls). In the second age group, there are ten four-year-old children (mean age: $4 ; 3$, range: $4 ; 0-4 ; 11$, four boys and six girls). In the last age group, ten fiveyear-olds (mean age: 5;1, range: 5;0-5;7, seven boys and three girls) are included in the study.

\subsection{Instruments and Setting}

There is a variety of methods for eliciting private speech according to the aim of the study such as puzzle placement (Pellegrini, 1981), Lego building (Berk and 
Spuhl, 1995), drawing (Matuga, 2003) or train ascending task (Feigenbaum, 1992). In the present study, data were collected in a room reserved for playtime activities in the kindergarten. Firstly, a proportionate table and chair suitable for the participants were placed across the wall on the right side of the room. Then, a camera that would record the child's actions and private speech utterances was placed on the right side of the child but a few steps away from the table the child is sitting at. Children could see the camera; therefore, they were probably aware of being recorded. However, they were not given information about being video recorded. On the table, a wooden toy house that had colourful removable household items was placed in a heap in front of the child. There were also toy family figures with parents, a daughter and a son. The researcher sat four or five meters behind the child with her laptop computer on her lap.

\subsection{Data Collection Process}

In order to elicit private speech data, children were recorded when they were playing with the toy house on their own. At the beginning of the session the child was given the following instruction: "Bu aile, bu evi yeni almış. Buraya taşınmışlar ama taşıyan adamlar eşyalarını buraya, dışarı bırakıp, onlara yardım etmeden gitmiş. Eşyalarını düzgünce eve yerleştirmelerine ve eve girmelerine yardım eder misin? Eşyaları istediğin gibi yerleştirebilirsin. Ben hemen arkada işimi yapıyor olacağım sonra gelip ne yaptığına bakacağım.” (This family has recently bought this house. They moved here but the porters left all these goods outside the house and left without helping them. Would you help them put all their stuff inside the house properly and get them in the house? You can do it the way you like. I will be right at the back and do some work of mine then I will come and look at what you have done.) After a few prompts for placing the pieces, the researcher left the child alone.

The recordings last between 10 to 20 minutes. However, if the child produced private speech effectively from the beginning, the first 15 minutes were included in the analysis.

\subsection{Data Analysis}

The present data is analysed basically through semantic categories of Winsler et al. (2003) with a few alterations in the categories such as dividing Questions category into two as Questions/Answers to the Self and to Imaginary Characters.

This categorization includes:

a) Exclamations: One-word affect expressions and expletives (e.g. Ah! Aman!) 
b) Non-words: Sound effects, wordplay, noises and humming (e.g. Hmm, sound of the water coming from the tap)

c) Description of Self: Statements about the child's state or behavior (e.g. Kendimi görüyorum. 'I can see myself.')

d) Descriptions of the Environment/Task: Statements about the setting or the task (e.g. Bu da mutfaktaki buzdolab1. 'This is the fridge in the kitchen.')

e) Evaluative and Motivational Statements: Statements about the child's self-reinforcement, ability, performance of the task or motivation. (e.g. Yaptım! 'I did it!', Güzel oldu. 'It is good.')

f) Plans/Hypothetical Reasoning: Plans or future-related statements, if-then statements. (e.g. O zaman bu da televizyon izleyecek. 'Then this one is going to watch $T V$.')

g) Commands to the Self: Explicit instructions given to the self by using an imperative verb. (e.g. Dur! 'Stop/Wait!', Yukarı çık! 'Go upstairs!')

h) Questions/Answers to the Self: Questions addressed by the child to himself/herself and clear answers to his/her own questions. (e.g. Bunu nereye koyuyorum? Buraya koyuyorum. 'Where do I put this? I put it here.')

i) Question/Answers of the Imaginary Characters: Questions addressed and answered by the toy family figures or imaginary characters. (e.g. Anne yemek hazır mi? 'Mom, is the breakfast ready?', Hayır daha hazırlamadik, babanla televizyon izliyoruz. 'No, we haven't prepared yet, we are watching $T V$ with dad.')

j) Transitional Statements: Reflective utterances upon finishing one activity and starting another one. (e. g. Tamam 'OK', Şimdi 'Now')

k) Other: Any utterance that could not be labeled as one of the above.

\section{Results}

In this section, in line with the aim of the research, the findings regarding the content of private speech are described in categories.

Content of private speech explains what the utterance refers to and what the child is talking about when using private speech. It gives the idea of the functions performed with private speech.

The categories used for the present analyses are adopted from Winsler et al. (2003) with a slight alteration by dividing Questions category into two as Questions and answers to the self and Questions and answers of the imaginary characters. Every private speech utterance was coded into one of these eleven categories based on its speech content, namely exclamations, non-words, description of the self, description of the environment and task, evaluative and motivational statements, plans/hypothetical reasoning, commands to the self, 
questions/answers to the self, questions/answers of the imaginary characters, transitional statements and other.

Table 3. The mean number of content categories of private speech across age groups

\begin{tabular}{lccc}
\hline & $\begin{array}{c}\text { 3-year-olds } \\
\text { (8 children) }\end{array}$ & $\begin{array}{c}\text { 4-year-olds } \\
\text { (10 children })\end{array}$ & $\begin{array}{c}\text { 5-year-olds } \\
\text { (10 children })\end{array}$ \\
\hline Exclamations & 1.13 & 1.40 & 0.70 \\
Wordplay/Noises & 1.38 & 0.30 & 1.80 \\
$\begin{array}{l}\text { Description of Self } \\
\text { Description of }\end{array}$ & 2.88 & 1.40 & 3.20 \\
Environment and & $\mathbf{2 4 . 2 5}$ & $\mathbf{1 3}$ & $\mathbf{1 4 . 9 0}$ \\
Task* & & & \\
$\begin{array}{l}\text { Motivational/Evaluative } \\
\text { Statements }\end{array}$ & 0 & 0 & 0.10 \\
Plans* & & & \\
Commands to the Self & 1.00 & $\mathbf{6 . 1 0}$ & $\mathbf{7 . 2 0}$ \\
Questions/ Answers & $\mathbf{7 . 8 8}$ & $\mathbf{4 . 7 0}$ & 0.40 \\
to the Self* & & & $\mathbf{7 . 1 0}$ \\
$\begin{array}{l}\text { Questions/Answers of } \\
\text { the Imaginary Characters }\end{array}$ & 0 & 0.70 & 0.70 \\
$\begin{array}{l}\text { Transitional Statements } \\
\text { Other } \\
\text { mean \# of all utterances }\end{array}$ & 1.13 & & \\
\hline
\end{tabular}

The results in Table 3 indicate the mean numbers in each category. We have observed that participants of this study used private speech for all categories indicated. Among the semantic categories, children in all age groups used private speech to describe the environment or task they are doing (See Example 1).

(1) CHI 27: Gece olmuş, bebecikler yatıyor. (M, 5;0)

It's night and the babies are sleeping. (As he puts the kids of the toy family in bed)

Children in the youngest group used these description of the environment and task statements more than the older age groups (Mean=24.25). Comparing three and four-year-olds in terms of the use of the same statements statistically shows that the decrease from three to four-year-olds' groups seems to be significant, that is right over $\mathrm{p}<0,05(\mathrm{p}=0,056)$. Although there is a decrease in the use of descriptive statements for the environment and task in four-year-olds' group 
(Mean=13.30), five-year-olds produced these statements slightly more than the children in four-year-olds' group (Mean=15,30). In general, the only significance is between three and four-year-olds' group this content category.

Questions and Answers to Self is the second most frequently preferred content category in all age groups. Children generally asked questions to speculate what or where the object is and did not answer their own questions verbally. However, in some cases, they asked and answered questions addressed at themselves as in Example 2.

(2) CHI 4: - Kumanda nerde?

- Where is the remote control?

- Aa burda kumanda! (M, 3;1)

- Oh here is the remote control!

Three and five-year-old children asked questions to self and answered their own questions almost in the same amount (three-year-olds' mean=7.88, five-yearolds' mean=7.10). Just as in the description of environment and task statements, a similar kind of decrease is observed in four-year-olds' groups, that is they asked and answered questions to self, less than the other age groups (Mean=4.70)

In some other cases, children created a dialogue between two family members and acted out their dialogue as in Example 3. Therefore "Questions/Answers" category was divided into two, as "Questions/Answers to the Self" and "Questions/Answers of the Imaginary Characters" where the child created a scenario, allocated roles to the toys and got them to talk and ask questions to each other.

(3) CHI 14: - Ooo çocuğum sen burda miydın?

- Oh kid, were you here?

- Evet anne. (M, 4;6)

- Yes, mom.

Children also used planning statements in their private speech. In these statements, they planned about placing the objects, used future oriented arrangements and produced if-then structures. There is a steady increase in the use of plans as children get older (Three, four and five-year-olds' means $=4,38$, 6,10 and 7,20 respectively). (See Example 4) 
(4) CHI 26: - Evin duvarı yapıcam [:yapacağım]. (M; 5;3)

- I'll build the wall of the house. (When he puts unrelated objects around the house)

When analysing description of self category, the difference between three and four (Means=2,88 and 1,40 respectively) and three and five-year-olds (Means=2,88 and 3,20 respectively) is not significant. However, when comparing four and five-year-olds' usage of description of self statements (Means=1,40 and 3,20 respectively), it is possible to see that the increase in the five-year-olds' group is statistically significant $(\mathrm{p}=0.030<0,05)$.

Motivational and evaluative statements are the least preferred content in private speech. Three and four-year-old children did not use these statements in their private speech at all. There was only one usage by a five-year-old girl when she places the TV stand on one corner and tries to get the boy figure to sit on a chair (See Example 5).

(5) İşte yaptım! (F, 5;9)

See, I did it!

Content of private speech gives the idea of what children talk about in their private speech and how they perform the functions of private speech. Findings on the content analysis revealed that children mostly described the environment and task, planned and asked and answered questions to themselves.

\section{Conclusion}

In the present study, content of private speech was studied. Private speech utterances were classified into 10 semantic categories formed by Winsler et al. (2003) who used a problem-solving task with three and four-year-olds with the aim of investigating the developmental change of private speech, syntactic abbreviation and task relevancy. The results of the present study revealed both similarities and differences in some of the categories which might be due to the nature of the tasks in the two studies. When similarities of the present study are compared with Winsler et. el.'s (2003) study, both in Turkish and English, children used the highest amount of private speech for description of the task. Similarly, in this category the amount of usages by three-year-olds was the highest and decreased as children got older. About describing one's own activities, Rubin (1979) proposed that making comments on one's own actions and feelings have the chance to "make young speakers aware of their own actions and of their own separate existences" (p. 291).

In Winsler et al. (2003) study, usages in description of the task are followed by other, transitional statements, and description of own activity categories. However, in Turkish, description of the task category is followed by questions to 
the self, plans and descriptions of own activity categories. Turkish children asked more questions to self and used planning function more than the ones in Winsler et. al (2003) study. The reason might be the nature of the task which required giving decisions on placing the pieces of the toy house. Furthermore, although the usages in planning category decreased in the older age group in their study, in the present study, children used more planning statements as they got older. Therefore, high usages in the categories of description of the environment and task, description of self, questions, and plans in Turkish pre-schoolers' private speech confirm Vygotsky's (1986) claims of the self-regulatory function of the private speech.

Age-related differences within the same category might be explained by the findings of Winsler, Carlton and Barry (2000). They found that "most four-yearold children's private speech occurred during the tacitly structured, self-selected activity classroom setting, focused, goal-directed activity and in the context of sustained activity. Whereas, three-year-old children's self-talk was more evenly distributed across the classroom contexts, more equally likely to appear during either goal-directed or unfocused activities, more equally likely to occur during either sustained or rapidly changing activities" (p. 680). They also interpret that four-year-olds tend to use private speech where it can serve its self-regulatory function more productively. As also stated by Johnson and Ershler (1981) compared to younger children, older children are more likely to keep their task behaviour for longer periods of time, create more complex play, and interact in cooperation with others.

In line with the above-mentioned literature, there are differences in the mean number of usages in the content of the utterances. In that, in most of the content categories including description of environment and task and questions to self, three-year-olds produced the highest amount of utterances than the older ones. In addition, utterances for planning increased as children get older proving that private speech provides self-regulatory function more with age.

\section{References}

Bayhan, P., \& Saranli, A. G. (2010). Vygotsky'nin kuramina dayanan kendine yönelik konuşma davranişinin okul öncesi dönemdeki gelişimi ve uygulamalarda kullanimi. Gazi Üniversitesi Gazi Ĕ̈itim Fakültesi Dergisi, 30(3), 819-834.

Berk, L. E. (1992). Children's private speech: an overview of theory and the status of research. In R. M. Diaz \& L. E. Berk (Eds), Private speech: from social interaction to self-regulation. (pp. 17-54) Hillsdale, NJ: Erlbaum.

Berk, L. E. (1994). Why children talk to themselves. Scientific American, 11,78-83.

Berk, L. E. and Spuhl, S. T. (1995). Maternal interaction, private speech and task performance in preschool children. Early Childhood Research Quarterly, 10, 145169. 
Copeland, A. P. (1979). Types of private speech produced by hyperactive and nonhyperactive boys. Journal of Abnormal Child Psychology,7, 169-177.

Demir, T. (2010). Konuşma eğitiminde benmerkezci konuşmaya yönelik bir deneme. Kastamonu Ĕ̈itim Dergisi, 18(2), 415-430.

Diaz, R. M. (1992). Methodological concerns in the study of private speech. In R. M. Diaz \& L. E. Berk (Eds), Private speech: from social interaction to self-regulation. (pp. 55-84) Hillsdale, NJ: Erlbaum.

Diaz, R., Winsler, A., Atencio, D. and Harbers, K. (1992). Mediation of self-regulation through the use of private speech. International Journal of Cognitive Education \& Mediated Learning, 2, 155-167.

Feigenbaum, P. (1992). Development of Syntactic and Discourse Structures of Private Speech. In R. M. Diaz and L. E. Berk (Eds.) Private speech: from social interaction to self-regulation. (pp. 181-198) Lawrence Erlbaum Associates, Publishers, New Jersey

Johnson, J. E. \& Ershler, J. (1981). Developmental trends in preschool play as a function of classroom program and child gender. Child Development 52, 995-1004.

Keleş, S., \& Alisinanoğlu, F. (2014). Observations and Views of Preschool Teachers about Private Speech Term of Vygotsky. Elementary Education Online, 13(1), 205222.

Krafft, K. C. and Berk, L. E. (1998). 'Private speech in two preschools: Significance of open-ended activities and make-believe play for verbal regulation'. Early Childhood Research Quarterly, 13(4), 637-658.

Matuga, J. M. (2003). Children's private speech during algorithmic and heuristic drawing tasks. Contemporary Educational Psychology, 28(4), 552-572.

Öztemür, G. (2018). Relationships between executive functioning, private speech, and emotion regulation in preschoolers (Unpublished master's thesis). Boğaziçi University, İstanbul.

Pellegrini, A. D. (1981). The development of preschoolers' private speech. Journal of Pragmatics, 5, 445-458.

Piaget, J. (1962). The language and thought of the child (M. Gabain, Trans.). Cleveland, OH: Meridian. (Original work published 1923).

Rubin, K.H. (1979). The impact of the natural setting on private speech. In G. Zivin (Ed.), The development of self-regulation through private speech (pp. 265-294). New York: Wiley

Rubin, K., and Dyck, L. (1980). Preschoolers' private speech in a play setting. MerrillPalmer Quarterly, 26, 219-229.

Vygotsky, L. V. (1986). Thought and language (A. Kozylin, Trans.), Cambridge, MA: MIT Press, (Original work published in 1934).

Winsler, A., Carlton, M. P., \& Barry, M. J. (2000). Age-related changes in preschool children's systematic use of private speech in a natural setting. Journal of Child Language, 27(3), 665-687.

Winsler, A., De León, J.R., Wallace, B., Carlton, M.P, \& Willson-Quayle, A. (2003). Private speech in preschool children: Developmental stability and change, across-task consistency, and relations with classroom behavior. Journal of Child Language. 